1 Biotechnological and Industrial Applications of Enzymes Produced by Extremophilic

\title{
Kelly Dumorné*
}

Departamento de Ingeniería Química, Facultad de Ciencias Químicas y Recursos Naturales, Universidad de La Frontera, Chile

*Corresponding author: Kelly Dumorné, Department of Engineering Chemical of Universidad de la Frontera, Avenida Francisco Salazar 01145, Box 54D. Temuco 4811230, Chile. Phone: +56959831512, Fax:+56 (045) 2325053, Email: k.dumorne01@,ufromail.cl

\section{Abstract}

Extremophilic bacteria are important groups of extremophilic organisms that have been studied during the last years. They are considered as a source of enzymes due to great diversity and can survive under extreme conditions. Many enzymes produced by these microorganisms are of great importance and have found applications in several industries. Due to their activity and stability under extreme conditions, these enzymes offer new alternatives for current biotechnological and industrial applications. They have a wide range of potential uses and have been a nuclear subject of many different investigations. To date, some of the enzymes produced by extremophilic bacteria are currently being assessed thier industrials applications. Despite, benefits that present these enzymes, their potentials remain largely unexplored. These enzymes pose new opportunities for new line of research, and biotechnological applications. This review provides a summary on diversity and biotechnological and industrial applications of some enzymes produced by extremophilic bacteria.

Keywords: extromphiles; extremophilic bacteria; enzymes; biotechnology application 


\section{Introduction}

The extremophiles are microorganisms that live in extreme conditions and adapt in environmental variables, such as at high and low temperatures, extremes of $\mathrm{pH}$, high salt concentrations, high pressure, and chemical extremes [1-3]. Studies about the extremophilic microorganisms have increased considerably in the last decades due to potential biotechnological applications. Enzymes produced by extremophilic bacteria have been receiving more attention due to biotechnological and industrial applications, also their stability [4-6]. Many enzymes have been isolated from extremophilic bacteria and these enzymes to play a crucial role as metabolic catalysts [7]. Several enzymes have been isolated from genera such as Bacillus, Corynebacterium glutamicum, Pseudomonas, Aletromonas, Halobacterium, Shewanella, Psychrobacter, Pseudoalteromonas, Arthrobacter, Colwellia, Gelidibacter, Marinobacter, Psychroflexus, Moritella, Halomonas, Photobacterium, Colwellia, Thioprofundum, Methanolobus and Methanococcoide [8-15]. With the growth and development of biotechnology, the interest for enzymes has increased considerably as a strategy towards attaining a biobased economy $[16,17]$. Enzymes from extremophilic bacteria have found major commercial applications. Enzymes such as polymerases, amylase, galactosidases, pullulanases, cellulase, xylanase, protease, esterase, ligases, pectinases, isomerases, dehydrogenases, chitinase, $\alpha$ glucosidases and endoglucanases have great potential application for biotechnology such as in pharmaceuticals industries, biofuel, cosmetics, nutritional supplements, molecular probes, food industries, enzymes, fine chemicals, animal feed and bioprocessing sustainable agriculture production of antibiotics, anticancer, and antifungal drugs. 
Other enzymes such as transaminases and dehalogenases, are currently being assessed their industrial applications [1]. Some of these enzymes have been purified and characterized in terms of their activity and stability profiles at different $\mathrm{pH}$, temperature. The exploration of enzymes with novel extreme activities and improved stability continues to be a priority objective in enzyme research. In this review, we briefly describe the enzymes more important from extremophilic bacteria and the most recent reports on the biotechnological applications.

\section{Enzymes produced by extremophilic bacteria.}

\subsection{Enzymes produced by acidophilic, alkaliphilic bacteria}

Acidophiles are microorganisms that live at $\mathrm{pH}$ below 3-4 [18]. Numerous enzymes have been produced by acidophilic and alkaliphilic microorganisms. Enzymes from acidophiles possess stability in acidic milieus and are active at $\mathrm{pH}$ low. Extremozymes from acidophiles possess a great potential for biotechnological and industrial applications especially in biofuel and ethanol production [19]. Nevertheless, the adaptation of some acidiphilic enzymes has not been clearly understood [20]. Enzymes produced by these microorganisms such as amylases, proteases, ligases, cellulases, xylanases, $\alpha$-glucosidases, endoglucanases, endo- $\beta$-glucanase and esterases possess a great potential for biotechnological and industrial applications [21, 22]. Enzyme as $\alpha$-glucosidases play important roles in carbohydrate metabolism, energy processing and glycosylation of lipids. The $\alpha$-glucosidase from Ferroplasma acidiphilum has demonstrated stability at low $\mathrm{pH}$ [23]. 
71 Proteases and esterases are enzymes with extensive applications in commercial and 72 physiological fields, whereas, amylases are one of the most important groups of enzymes with extensive applications in the conversion of starch to sugar syrups, and in the bread and textile industries [24]. These enzymes are very stable in organic solvents. Currently, these enzymes are used in starch industry is active at $\mathrm{pH}$ 6.5. Alkaline enzymes have a dominant position in the global enzyme market especially in detergents [25]. These enzymes are stable, also, have good activity in saline conditions [26]. Despite, their stability alkaliphilic enzyme have not been exploited for biotechnological and industrial applications [27]. Some enzymes produced by alkaliphilic microorganisms such as xylanases, amylases, proteases, dextranases, xylosidases, chitinases, cellulase, alginases, catalase, RNase, DNase, cellulases, glucose dehydrogenase, $\alpha$-galactosidase, $\beta$ - galactosidase, pectinase, $\beta$ mannanase, uricase, oxidase, $\beta$ - mannosidase and lipases have been used in several biotechnological applications such as industries of food, bioremediation, biosynthetic processes pharmaceutical industries detergents, leather processing, waste management and textile industry [8]. For example, protease, cellulase, lipase and amylase are generally put in detergents as additives, these enzymes contribute to an improvement of the washing power, they have activity and stability in detergents. Proteases are very important for industrial enzymes. In the market, their sales amount to $60 \%$ of the total enzymes [25]. Proteases produced by members of Bacillus uses mainly in detergent formulations, additionally, these enzymes use in contact lens solutions, in cheese production, processing of meat products, and for the recovery of silver from photographic films [28-30]. Numerous research have shown that lipases from bacteria are stable at $\mathrm{pH}$ between 4 to 11 [31]. 
93 Amylases are other enzymes that are very important for several industries. These enzymes produce manly by Bacillus subtilis, Bacillus licheniformis, Bacillus amyloliquefaciens, and Bacillus megaterium [32]. In detergents, amylases have an activity at $\mathrm{pH}$ between $8-11$, these enzymes have a practical use in the laundry industry [33]. Xylanases from alkaliphilic bacteria have various biotechnological and industrial applications such as in the prebleaching of pulp, conversion of lignocellulosic biomass to serve as source of biofuel, improvement of cereal food products and animal feedstocks, and degumming of plant fibers, these enzymes are stable at broad ranges of $\mathrm{pH}[34,35]$. Regarding alkaline pectinases have found various applications biotechnological mainly during fiber processing for usage in textiles and during the paper-making process [36, 37]. Pectinases have been produced from several microorganisms of Bacillus sp. For example pectinase from Bacillus subtilis SS can be to increase the brightness, whiteness, and fluorescence of paper pulp, thus improving characteristics of paper [38]. Some enzymes produced by extromophilic bacteria have been produced in great quantities at low cost, and have been commercialized [39].

\subsection{Enzymes from psychrophilic and thermophilic bacteria}

Psychrophiles are microorganisms that live in cold environments from the deep sea to mountain and polar regions [40]. They are a source of enzymes that can be use in different innovative reactions applicable to industry [41]. Enzymes from psychrophilic microorganisms have a structural flexibility and high catalytic efficiency [42]. There are numerous benefits to the application of psychrophilic enzymes such as the high diversity, high yield, immense stability, high catalytic activity and economic feasibility highlighted its biotechnological potential and industrial applications [17, 18]. 
117 In recent years, numerous research and various industrials have increased efforts to

118 discover and develop novel cold-adapted enzymes. The cold adapted enzymes have been 119 evolved in psychrophilic bacteria as a strategy for low temperature adaptation [43-45].

120 Enzymes produced by psychrophilic bacteria such as alkaline phosphatases, glycosylases,

121 nucleases, lipases, proteases, amylases, cellulases, mannanases, pectate lyases, amylases,

122 DNA ligase, endo-arabinanase, polygalacturonase, cellulases, pectinases and catalase have

123 great potential application for biotechnology in detergent, textile, food, beverages and

124 cosmetic applications including many techniques used in molecular biology. Proteases from

125 psychrophilic bacteria have use in detergent industries [46, 47]. Other enzymes such as

126 amylase, cellulases, dehydrogenases, $\beta$-glucanase, pectinases y DNA polymerases have

127 been used to improve the efficacy of cold-water household, also, in textiles, biosensors,

128 maturing cheeses, milk products, processing of fruit juices [48, 49]. Recently, a novel

129 cold-adapted cellulase complex from an earthworm living in a cold environment was

130 discovered that contained both endo- $\beta$-1,4-D-glucanase and $\beta-1,4$-glucosidase activities

131 that could convert cellulose directly into glucose [47]. Cold-adapted enzymes have

132 potential application in mixed aqueous-organic or non-aqueous solvents for the purpose of

133 organic synthesis. Thus, cold adapted enzymes provide a strategy to psychrophilic

134 microorganism for cold adaption at low temperature [50]. Genera such as

135 Caldicellulosiruptor, Thermotoga maritima and Thermus, are among the most studied

136 thermophiles to date [51]. Enzymes produced by thermophilic microorganisms such as

137 cellulases, xylanases, mannanase, pectinases, chitinases, amylases, pullulanases, proteases,

138 lipases, glucose isomerases, alcohol dehydrogenases, and esterases have great

139 biotechnological applications [52-54]. 
140 For example, xylanases from Thermus brockianus and Thermotoga thermarum are

141

142

143

144

145

146

147 considered appropriate for industrial applications, due to high optimal reaction temperature of $95{ }^{\circ} \mathrm{C}$, stability and high specific activity [55]. Currently, proteases, lipases and gylcosyl hydrolases, account for more than $70 \%$ of all enzymes sold. Proteases are the most sold and used of enzymes thermophilic. Proteases have numerous biotechnological and industrials applications, however, the largest application is in laundry detergents, are used to break apart and remove stains. Lipase is other important enzyme, has been used for various industrial applications such as paper industry, milk industry, in processing of dyed products, leather industry and in pharmaceuticals $[1,55]$. Currently, various lipases have been widely purified and characterized from different microorganisms without losing their activity and stability profiles depending to $\mathrm{pH}$, temperature and effects of metal ions and chelating agents. This purification is important for some industries such as fine chemicals, pharmaceuticals and cosmetics. The techniques more common used are nonspecific techniques, extraction, precipitation, hydrophobic interaction, chromatography, gel filtration, affinity chromatography, crystallization and ion exchange chromatography. The alcohol dehydrogenases (ADHs) are considered as one of the most interesting enzyme groups from thermophilic microorganisms. The ADHs was amplified by PCR and overexpressed in Escherichia coli. Currently, a new carboxyl esterase has been identified form Thermogutta terrifontis from and phylum Planctomycetes. This enzyme is very thermostable and retained $95 \%$ of its activity after incubation. The enzymes produced by thermophilic bacteria are stable to high temperature, presence of solvents, and resistance to proteolysis, are ideal features for industrial applications [56, 57]. 
163

164

165

166

167

168

169

170

171

172

173

174

175

176

177

178

179

180

181

182

183

184

185

\subsection{Enzymes from halophilic bacteria}

Halophilic bacteria are considered as one of the most important extremophiles, they can be found in saline or hypersaline environments. Enzymes from halophilic bacteria are considered as a novel alternative for use as biocatalysts in different industries. Currently, there are few studies on halophilic enzymes [58]. Due to unique properties, halophilic microorganisms have been explored for their biotechnological potential in different fields [59]. Enzymes produced by halophilic microorganisms offer important opportunities in biotechnological applications such as food processing, environmental bioremediation, biosynthetic processes fermented food, textile, pharmaceutical and leather industries [60]. These enzymes are stable at high salt concentrations, but also can withstand and carry out reactions efficiently under extreme conditions such as high $\mathrm{pH}$ values, high or low temperature, low oxygen availability, pressure, and toxic metals [61, 62]. Enzymes such as xylanases, dehydrogenase, amylases, proteases, $\alpha$-amylases and lipases, have been produced by different genera of halophilic bacteria such as Cyanobacteria, Proteobacteria, Firmicutes, Actinobacteria, Spirochaetes Salinivibrio, Halomonas, Bacillus-Salibacillus and Bacteroidetes, Pseudoalteromonas ruthenica and Bacillus, Halobacillus and Thalassobacillus. These enzymes have been commercialized especially in the production of polyunsaturated fatty acids, food, biodiesel, baking, feed, chemical and pharmaceutical, paper and pulp, detergent, leather industries, fish sauce and soy sauce preparations, saline waste water, and oilfield waste treatment [63-66]. Lipases, proteases and amylases isolated from halophilic bacteria constitute an excellent alternative in the industrial processes due to their stability and versatility [67]. Hydrolases is other enzymes characterized from halophilic bacteria [68]. 
186 During the last years, the halophiles have developed of novel enzymes. These enzymes

187 have unique structural features and catalytic power to sustain the metabolic and 188 physiological processes under high salt conditions $[69,70]$. Due to stability under high salt 189 concentrations, the demand for enzymes produced by halophiles has increased considerably 190 [71]. Various investigations have reported on production or purification of haloenzymes 191 from halophilic bacteria, resistance of the enzymes toward different organic solvents has 192 been examined [72]. Enzymes produced by halophilic bacteria show interesting properties 193 for use in different biotechnological and industrial applications.

\section{Conclusions}

Currently, exists numerous publications that considerable diversity,

197 biotechnological and industrial applications of enzymes produced by extremophilic 198 bacteria, however, many remain to be explore. Despite, the advantages that offer these 199 enzymes have not been exploited their potentials and, the actual number available is very limited. Extremophilic bacteria are a good source to produce enzymes, however, it presents some difficulties such as high and low $\mathrm{pH}$, high temperatures or high concentration of salts, high pressure, chemicals, organic solvents normally require bioreactors under extreme conditions. Many enzymes produced by extremophilic bacteria are commercially available. Current, the market leaders in commercial enzyme production are Novozymes A/S, Genencor International, Inc. and DSM N.V, however, these market leaders need to develop of new industrial processes and new methods especially, in biochemistry, microbiology and

207 genetic engineering based on enzymes are required. The increasing demand of enzymes are 208 of great interest for extremophile investigation. 
209 Enzymes produced by extremophiles especially from bacteria have great potential 210 biotechnological applications such as in agriculture, food beverages, pharmaceutical, 211 detergent, textile, leather, pulp and paper, and biomining industries. Currently, the use of

212

213

214

215 enzymes requires the adaptation and creation of new methodologies, assays, and techniques that operate under conditions extreme. To date, the discovery of new enzymes based on genetic sequences require more research especially for extremophiles. The extremophilic microorganisms are sustainable sources that might be better exploited in several biotechnological areas towards the expansion of a bio-based economy. Extremozymes have had a large impact so far from a commercial and biotechnological perspective. In conclusion, the development of novel molecular tools, more efficient production processes, and novel technologies will further advance the application of enzymes in different industries.

\section{Acknowledgments}

The authors are sincerely thankful for the support provided by University de la Frontera and the Department of Chemical Engineering. This work was supported by Fund for Scientific and Technological Research FONDECYT (1151315) and Universidad de la Frontera Scholarships for $\mathrm{PhD}$ in Chile (KD).

Conflicts of Interest: The author declare no conflict of interest. 


\section{Reference}

1. Dumorné, K.; Cordova, D.C.; Astorga-Elo, M.; Renganathan, P. Extremozymes: A potential source for industrial applications. Journal of Microbiology and Biotechnology 2017, 27, 649-659.

2. Navarro-González, R.; Iniguez, E.; de la Rosa, J.; McKay, C.R. Characterization of organics, microorganisms, desert soil, and Mars-like soils by thermal volatilization coupled to mass spectrometry and their implications for the search for organics on Mars by Phoenix and future space missions. Astrobiology 2009, 9, 703-711.

3. Cavicchioli, R.; Amils, D.; McGenity, T.. Life and applications of extremophiles. Environ. Microbiol. 2011, 13, 1903-1907.

4. Cárdenas, J.P.; Valdés, J.; Quatrini, R.; Duarte, F.; Holmes, D.S. Lessons from the genomes of extremely acidophilic bacteria and archaea with special emphasis on bioleaching microorganisms. Appl. Microbiol. Biotechnol. 2010, 88, 605-620.

5. López-López, O.; Cerdán, M.E.; González-Siso, M.I. New extremophilic lipases and esterases from metagenomics. Curr. Protein Pept. Sci. 2014, 15, 445-455.

6. Yildiz, S.Y.; Radchenkova, N.; Arga, K.Y.; Kambourova, M.; Toksoy, O.E. Genomic analysis of Brevibacillus thermoruber 423 reveals its biotechnological and industrial potential. Appl. Microbiol. Biotechnol. 2015, 99, 2277-2289.

7. Adrio, J.L.; Demain, A.L. Microbial Enzymes: Tools for Biotechnological Processes. Biomolecules 2014, 4, 117-139.

8. Chen, G.Q.; Jiang, X.R. Next generation industrial biotechnology based on extremophilic bacteria. Current Opinion in Biotechnology 2017, 50, 94-100.

9. Zhang, Y.; Li, X.; Bartlett, D.H.; Xiao, X. Current developments in marine microbiology: high-pressure biotechnology and the genetic engineering of piezophiles. Curr Opin Biotechnol. 2015, 33, 157-164.

10. De Maayer, P.; Anderson, D.; Cary, C.; et al. Some like it cold: understanding the survival strategies of psychrophiles. EMBO Rep. 2014, 15, 508-517.

11. Dopson, M.; Holmes, D.S. 2014. Metal resistance in acidophilic microorganisms and its significance for biotechnologies. Appl Microbiol Biotechnol. 2014, 98, 8133-8144.

12. Johnson, D.B. 2014. Biomining-biotechnologies for extracting and recovering metals from ores and waste materials. Curr Opin Biotechnol. 2014, 30, 24-31.

13. Gabani, P.; Singh, O.V. 2013. Radiation-resistant extremophiles and their potential in biotechnology and therapeutics. Appl Microbiol Biotechnol. 2013, 97, 993-1004.

14. Gtari, M.; Essoussi, I.; Maaoui, R.; Sghaier, H.; Boujmil, R.; Gury, J.; et al. Contrasted resistance of stone dwelling Geodermatophilaceae species to stresses known to give rise to reactive oxygen species. FEMS Microbiol Ecol. 2012, 80, 566-577. 
15. Sarethy, I.P.; Saxena, Y.; Kapoor, A.; Sharma, M.; Sharma, S.K.; Gupta, V.; et al. Alkaliphilic bacteria: applications in industrial biotechnology. J. Ind. Microbiol. Biotechnol. 2011, 38, 769-790.

16. Raddadi, N.; Cherif, A.; Daffonchio, D.; Mohamed, N.; Fava, F. 2015. Biotechnological applications of extremophiles, extremozymes and extremolytes. Appl. Microbiol. Biotechnol. 2015, 99, 7907-7913.

17. Sarmiento, F.; Peralta, R.; Blamey, J.M. 2015. Cold and Hot Extremozymes: Industrial Relevance and Current Trends. Front Bioeng Biotechnol. 2015, 3, 148.

18. Gurung, N.; Ray, S.; Bose, S.; Rai, V. A broader view: microbial enzymes and their relevance in industries, medicine, and beyond. Biomed. Res. Int. 2013, 2013, 329-121.

19. Jackson, B.R.; Noble, C.; Lavesa-Curto, M.; Bond, P.L.; Bowater, R.P. Characterization of an ATP-dependent DNA ligase from the acidophilic archaeon "Ferroplasma acidarmanus" Fer1. Extremophiles 2007, 11, 315-327.

20. Sharma, A.; Parashar, D.; Satyanarayana, T. Acidophilic Microbes: Biology and Applications. P.H. Rampelotto (ed.), Biotechnology of Extremophiles, Grand Challenges in Biology and Biotechnology. 2016. doi: 10.1007/978-3-319-13521-2_7

21. Sun, S.N.; Sun, S.L.; Cao, X.F.; Sun, R.C. The role of pretreatment in improving the enzymatic hydrolysis of lignocellulosic materials. Biores Technol. 2016, 199, 49-58.

22. Xian, L.; Wang, F.; Luo, X.; Feng, Y.L.; Feng, J.X. Purification and characterization of a highly efficient calcium-independent $\alpha$-amylase from Talaromyces pinophilus 1-95. PLoS One 2015, 10, e0121531.

23. Sharma, A.; Kawarabayasi, Y.; Satyanarayana, T. Acidophilic bacteria and archaea: acid stable biocatalysts and their potential applications. Extremophiles 2012, 16, 1-19.

24. Fujiwara, S. 2002. Extremophiles: developments of their special functions and potential resources. J. Biosci. Bioeng. 2002, 94, 518-525.

25. Chinnathambi, A. 2015. Industrial Important Enzymes from Alkaliphiles - An overview. Biosciences Biotechnology Research 2015, 12, 2007-2016.

26. Ahmed, E.H.; Raghavendra, T.; Madamwar, D. An alkaline lipase from organic solvent tolerant Acinetobacter sp. EH28: application for ethyl caprylate synthesis. Bioresour Technol. 2010, 10, 3628-3634.

27. Huang, Y.; Krauss, G.; Cottaz, H.; Driguez, H.; Lipps, G. 2005. A highly acid-stable and thermostable endo- $\beta$-glucanase from the thermoacidophilic archaeon Sulfolobus solfataricus. Biochem. J. 2005, 385, 581-588.

28. Gupta, R.; Beg, Q.K.; Lorenz, P. 2002. Bacterial alkaline proteases: molecular approaches and industrial applications. Appl Microbiol Biotechnol. 2002, 59, 15-32.

29. Ito, S.; Kobayashi, T.; Ara, K.; Ozaki, K.; Kawai, S.; Hatada, Y. Alkaline detergent enzymes from alkaliphiles: enzymatic properties, genetics, and structures. Extremophiles 1998, 2,185-190. 
30. Rao, M.B.; Tanksale, A.M.; Ghatge, M.S.; Deshpande, V.V. Molecular and biotechnological aspects of microbial proteases. Microbiol. Mol. Biol. Rev. 1998, 62, $597-$ 635.

31. Gupta, R.; Gupta, N.; Rathi, P. 2004. Bacterial lipases: an overview of production, purification and biochemical properties. Appl Microbiol Biotechnol. 2004, 64, 763-781.

32. Sivaramakrishnan, S.; Gangadharan, D.; Nampoothiri, K.M.; Soccol, C.R.; Pandey, A. $\alpha$-amylases from microbial sources an overview on recent developments. Food Technol Biotechnol. 2006, 44, 173-184.

33. Kapoor, M.; Beg, Q.K.; Bhushan, B.; Singh, K.; Dadhich, K.S.; Hoondal, G.S. 2001. Application of an alkaline and thermostable polygalacturonase from Bacillus sp. MG-cp-2 in degumming of ramie (Boehmeria nivea) and sunn hemp (Crotalaria juncea) bast fibres. Process Biochem. 2001, 36, 803-807.

34. Li, X.T.; Jiang, Z.Q.; Li, L.T.; Yang, Q.S.; Feng, W.Y.; Fan, J.Y.; Kusakabe, I. 2005. Characterization of a cellulase-free, neutral xylanase from Thermomyces lanuginosus CBS 288.54 and its biobleaching effect on wheat straw pulp. Bioresour Technol. 2005, 96, 13701379.

35, Sanghi, A.; Garg, N.; Gupta, V.K.; Mittal, A.; Kuhad, R.C. Onestep purification and characterization of cellulase-free xylanase produced by alkalophilic Bacillus subtilis ash. Braz J Microbiol. 2010, 41, 467-476.

36. Hoondal, G.S.; Tiwari, R.P.; Tewari, R.; Dahiya, N.; Beg, Q.K. Microbial alkaline pectinases and their industrial applications: a review. Appl Microbiol Biotechnol. 2002, 59, 409-418.

37. Kashyap, D.R.; Vohra, P.K.; Chopra, S.; Tewari, R. Application of pectinase in the commercial sector: a review. Bioresour Technol. 2001, 77, 215-227.

38. Ahlawat, S.; Mandhan, R.P.; Dhiman, S.S.; Kumar, R.; Sharma, J. 2008. Potential application of alkaline pectinase from Bacillus subtilis SS in pulp and paper industry. Appl Biochem Biotechnol. 2008, 149, 287-293.

39. Horikoshi, K. Alkaliphiles: Genetic Properties and Applications of Enzymes, SpringerVerlag, Berlin. 2006, 276

40. D'Amico, S.; Collins, T.; Marx, J.C.; Feller, G.; Gerday, C. Psychrophilic microorganisms: challenges for life. EMBO reports. 2006, 7, 385-389.

41. Van den Burg, B. 2003. Extremophiles as a source for novel enzymes. Curr. Opin. Microbiol. 2003, 6, 213-218.

42. Siddiqui, K.S.; Cavicchioli, R. Cold-adapted enzymes. Annu. Rev. Biochem. 2006, 75, 403-433. 
43. Singh, A.K.; Pindi, P.K.; Dube, S.; Sundareswaran, V.R.; Shivaji, S. Importance of trmE for growth of the psychrophile Pseudomonas syringae at low temperatures. Appl. Environ. Microbiol. 2009, 75, 4419-4426.

44. Singh, A.K.; Shivaji, S. A cold-active heat-labile t-RNA modification GTPase from a psychrophilic bacterium Pseudomonas syringae (Lz4W). Res Microbiol. 2010, 161, 46-50.

45. Sundareswaran, V.R.; Singh, K.; Dube, S.; Shivaji, S. Aspartate aminotransferase is involved in cold adaptation in psychrophilic Pseudomonas syringae. Arch Microbiol. 2010, 192, 663-672.

46. Singh, V.; Singh, M.P.; Verma, V.; Singh, P.; Srivastava, R.; et al. Characteristics of Cold Adapted Enzyme and Its Comparison with Mesophilic and Thermophilic Counterpart. Cell Mol Biol. 2016, 62, 144.

47. Ueda, M.; Goto, T.; Nakazawa, M.; Miyatake, K.; Sakaguchi, M.; Inouye, K. A novel cold-adapted cellulase complex from Eisenia foetida: characterization of a multienzyme complex with carboxymethylcellulase, beta-glucosidase, beta-1,3 glucanase, and betaxylosidase. Comp. Biochem. Physiol. B Biochem. Mol. Biol. 2010, 157, 26-32.

48. Cavicchioli, R. Extremophiles and the search for extraterrestrial life. Astrobiology 2002, 2, 281-292.

49. Fusi, P.; Grisa, M.; Mombelli, E.; Consonni, R.; Tortora, P.; Vanoni, M. Expression of a synthetic gene encoding P2 ribonuclease from the extreme thermoacidophilic archaebacterium Sulfolobus solfataricus in mesophylic hosts. Gene 1995, 54, 99-103.

50. Jaenicke, R. Enzymes under extreme of physical conditions. Annu. Rev. Biophys. Bioeng. 2001, 10:1-67.

51. Brim, H.; Venkateswaran, A.; Kostandarithes, H.M.; Fredrickson, J.K.; Daly, M.J. 2003. Engineering Deinococcus geothermalis for bioremediation of high-temperature radioactive waste environments. Appl Environ Microbiol. 2003, 69, 4575-4582.

52. Elleuche, S.; Schroder, C.; Sahm, K., Antranikian, G. Extremozymes biocatalysts with unique properties from extremophilic microorganisms. Curr Opin Biotechnol. 2014, 29, 116-123.

53. Chai, Y.Y.; Rahman, R.N.; Illias, R.M.; Goh, K.M. Cloning and characterization of two new thermostable and alkalitolerant $\alpha$-amylases from the Anoxybacillus species that produce high levels of maltose. J Ind Microbiol Biotechnol. 2012, 39, 731-741. doi: 10.1007/s10295-011-1074-9.

54. Saul, D.; Morgan, H.W.; Bergquist, P.L. Selected enzymes from extreme thermophiles with applications in biotechnology. Curr Biotechnol. 2014, 3, 45-59.

55. Blank, S.; Schroder, C.; Schirrmacher, G.; Reisinger, C.; Antranikian, G. Biochemical characterization of a recombinant xylanase from Thermus brockianus, suitable for biofuel production. JSM Biotechnol Bioeng. 2014, 2, 1027.

56. Birgisson, H.; Delgado, O.; Arroyo, L.G.; Hatti-Kaul, R.; Mattiasson, B. Cold-adapted yeasts as producers of cold-active polygalacturonases. Extremophiles 2003, 7, 185-193. 
57. Bruins, M.E.; Janssen, A.E.; Boom, R.M. Thermozymes and their applications: a review of recent literature and patents. Appl. Biochem. Biotechnol. 2001, 90, 155-186.

58. Yu, H.Y.; Li, X. Purification and characterization of novel organic-solvent-tolerant bamylase and serine protease from a newly isolated Salimicrobium halophilum strain LY20. FEMS Microbiol. Lett. 2012, 329, 204-211.

59. Sorokin, D.Y.; Tindall, B.J. 2006. The status of the genus name Halovibrio. Fendrich 1988 and the identity of the strains Pseudomonas halophila DSM 3050 and Halomonas. variabilis DSM 3051. Request for an opinion. Int. J. Syst. Evol. Microbiol. 2006, 56, $487-$ 489.

60. De Lourdes Moreno, M.; Pérez, D.; García, M.T.; Encarnación Mellado, E. 2013. Halophilic Bacteria as a Source of Novel Hydrolytic Enzymes. Life 2013, 3, 38-51.

61. Datta, S.; Holmes, B.; Park, J.; Chen, Z.; Dibble, D.C.; Hadi, M.; et al. 2010. Ionic liquid tolerant hyperthermophilic cellulases for biomass pretreatment and hydrolysis. Green Chem. 2010, 12, 338-345.

62. Kumar, S.; Karan, R.; Kapoor, S.; Singh, S.P.; Khare, S.K. Screening and isolation of halophilic bacteria producing industrially important. Brazilian Journal of Microbiology 2012, 2012, 1595-1603.

63. Schreck, S.D.; Grunden, A.M. Biotechnological applications of halophilic lipases and thioesterases. Appl. Microbiol. Biotechnol. 2014, 98, 1011-1021. doi: 10.1007/s00253-0135417-5.

64. Litchfield, C.D. Potential for industrial products from the halophilic Archaea. J. Ind. Microbiol. Biotechnol. 2011, 38, 1635-1647.

65. Munawar, N.; Engel, P.C. Overexpression in a non-native halophilic host and biotechnological potential of $\mathrm{NAD}+-$ dependent glutamate dehydrogenase from Halobacterium salinarum strain NRC-36014. Extremophiles 2012, 16, 463-476.

66. Ruiz, D.M.; De Castro, R.E. Effect of organic solvents on the activity and stability of an extracellular protease secreted by the haloalkaliphilic archaeon Natrialba magadii. J. Ind. Microbiol. Biotechnol. 2007, 34, 111-115.

67. Pikuta, E.V.; Hoover, R.B.; Tang, J. Microbial extremophiles at the limits of life. Crit. Rev. Microbiol. 2007, 33, 183-209.

68. Moreno, M.L.; García, M.T.; Ventosa, A.; Mellado, E. Characterization of Salicola sp. IC10, a lipase- and protease-producing extreme halophile. FEMS Microbiol. Ecol. 2009, $68,59-71$.

69. Ghasemi, Y.; Rasoul-Amini, S.; Kazemi, A.; Zarrini, G.; Morowvat, M.H.; Kargar, M. Isolation and characterization of some moderately halophilic bacteria with lipase activity. Microbiology 2011, 80, 483-487.

70. Kuberan, T.; Sangaralingam, S.; Thirumalaiarasu, V. Isolation and optimization of protease producing bacteria from halophilic soil. Journal of Biosocial Science 2010, 1, 163 174 
421 71. Oren, A. Industrial and environmental applications of halophilic microorganisms. Environmental Technology 2010, 31, 825-834.

72. Doukyu, N.; Ogino, H. Organic solvent-tolerant enzymes. Biochem Eng J. 2010, 48, 270-282.

73. Gerday, C.; Aittale, M.; Bentahir, M.; Chessa, J.P.; Claverie, P.; Collins, T.; et al. Coldadapted enzymes: from fundamentals to biotechnology. Trends Biotechnol. 2000, 18, 103107.

74. Huang, H.; Luo, H.; Wang, Y.; Fu, D.; Shao, N.; Yang, P.; et al. Novel lowtemperature-active phytase from Erwinia carotovora var. carotovota ACCC 10276. J. Microbiol. Biotechnol. 2009, 19, 1085-1091.

75. Ueda, M.; Asano, T.; Nakazawa, M.; Miyatake, K.; Inouye, K. Purification and characterization of novel raw-starch-digesting and cold-adapted $\alpha$-amylases from Eisenia foetida. Comp. Biochem. Physiol. Part B. 2008a, 150, 125-130.

76. Wang, F.; Hao, J.; Yang, C.; Sun, M. Cloning, expression, and identification of a novel extracellular cold-adapted alkaline protease gene of the marine bacterium strain YS 80-122. Appl. Biochem. Biotechnol. 2010, 162, 1497-1505.

77. Parkes, R.; Cragg, J.; Banning, B.A.; Brock, N.; Webster, F.; Fry, G.; et al. Biogeochemistry and biodiversity of methane cycling in subsurface marine sediments (Skagerrak, Denmark). Environ. Microbiol. 2007, 9, 1146-1161.

78. Aurilia, V.; Parracino, A.; D'Auria, S. Microbial carbohydrate esterases in cold adapted environments. Gene 2008, 410, 234-240.

79. Amoozegar, M.A.; Siroosi, M. Hydrolytic Enzymes in Halophilic Bacteria, Properties and Biotechnological Potential. In: Maheshwari D., Saraf M. (eds) Halophiles. Sustainable Development and Biodiversity, Springer, Cham. 2015, 6 .

80. Toplin, J.A.; Norris, T.B.; Lehr, C.R.; McDermott, T.R.; Castenholz, R.W. Biogeographic and phylogenetic diversity of thermoacidophilic Cyanidiales in Yellowstone National Park, Japan, and New Zealand. Appl. Environ. Microbiol. 2008, 74, 2822-2833.

81. Singh, B.K. Exploring microbial diversity for biotechnology: the way forward. Trends Biotechnol. 2010, 28, 111-116.

82. Zeng, X.; Birrien, J.L.; Fouquet, Y.; Cherkashov, G.; Jebbar, M.; Querellou, J.; et al. Pyrococcus $\mathrm{CH} 1$, an obligate piezophilic hyperthermophile: extending the upper pressure temperature limits for life. ISME J. 2009, 3, 873-876.

83. Taylor, I.N.R.; Brown, C.; Rycroft, M.; King, G.; Littlechild, J.A.; Lloyd, M.C.; et al. Application of thermophilic enzymes in commercial biotransformation processes. Biochem. Soc. Trans. 2004, 32, 290-292.

84. Egorova, K.; Antranikian, G. Industrial relevance of thermophilic Archaea. Curr. Opin. Microbiol. 2005, 8, 649-655. 
458 85. De Champdoré, M.; Staiano, M.; D’Auria, S. Proteins from extremophiles as stable 459 tools for advanced biotechnological applications of high social interest. J. R. Soc. Interface 460 2007, 4, 183-191.

461 86. Joseph, B.; Ramteke, P.W.; Thomas, G. 2008. Cold active microbial lipases: some hot 462 issues and recent developments. Biotechnol. Adv. 2008, 26, 457-470.

463 87. Schmid, A.K.; Reiss, D.J.; Pan, M.; Koide, T.; Baliga, N.S. A single transcription factor 464 regulates evolutionarily diverse but functionally linked metabolic pathways in response to 465 nutrient availability. Mol. Syst. Biol. 2009, 5, 282-294.

466 88. Collins, T.; D’Amico, S.; Marx, J.C.; Feller, G.; Gerday, C. Cold-adapted enzymes, pp. 467 165-179. In Gerday $\mathrm{C}$, Glansdorff $\mathrm{N}$ (eds.). Physiology and Biochemistry of 468 Extremophiles. ASM Press, Washington, DC. USA. 2007.

469 89. Nicholas, J.R. Antarctic microorganism: coming in from the cold. Culture 2006, 27, $470 \quad 965-989$

471

472

473

474

475 
Table 1. Biotechnological and industrial applications of some enzymes more important from extremophilic bacteria.

\begin{tabular}{|c|c|c|c|c|c|c|}
\hline Types & $\begin{array}{c}\text { Growth } \\
\text { characteristics }\end{array}$ & $\begin{array}{l}\text { Environment/source/ } \\
\text { Geographical location } \\
\end{array}$ & Genus & Enzymes & Application & Reference \\
\hline \multirow[t]{4}{*}{ Acidophile } & $\begin{array}{l}\text { Organism that grows at } \\
\text { pH optimum below 3- } \\
4\end{array}$ & $\begin{array}{l}\text { Acid Mine Drainage Volcanic } \\
\text { Springs, USA }\end{array}$ & $\begin{array}{l}\text { Sulfolobus } \\
\text { solfataricus } \\
\text { Acetobacter }\end{array}$ & $\begin{array}{c}\text { Amylase } \\
\text { Glucoamylase }\end{array}$ & $\begin{array}{l}\text { Starch processing. } \\
\text { Single-cell protein from } \\
\text { shellfish waste. }\end{array}$ & [73] \\
\hline & & & & Proteases & $\begin{array}{l}\text { Animal feed for the } \\
\text { improvement of } \\
\text { Digestibility. }\end{array}$ & {$[74,75]$} \\
\hline & & & & Cellulases & $\begin{array}{l}\text { Removal of hemicellulosic } \\
\text { material from feed. } \\
\text { Feed component. }\end{array}$ & {$[76]$} \\
\hline & & & & Oxidases & Desulfurization of coal. & \\
\hline Alkaliphile & $\begin{array}{l}\text { Organism that grows at } \\
\mathrm{pH} \text { optimum above } 10\end{array}$ & Soda Lakes, Utah USA. & $\begin{array}{c}\text { Bacillus, } \\
\text { Micrococcus, } \\
\text { Pseudomonas, } \\
\text { Actinobacteria }\end{array}$ & Proteases & $\begin{array}{l}\text { Detergents, food, and feed. } \\
\text { Fermentation of beer and } \\
\text { wine, breadmaking, and fruit } \\
\text { juice processing. }\end{array}$ & {$[1,41,77]$} \\
\hline Halophile & $\begin{array}{l}\text { Organism that requires } \\
\text { at least } 1 \mathrm{M} \\
\text { (manily } \mathrm{NaCl} \text { ) }\end{array}$ & Salt Lakes, Utah USA & $\begin{array}{l}\text { Halobacterium } \\
\text { Halococcus } \\
\text { Bacillus }\end{array}$ & Proteases & Peptides synthesis & {$[8,78]$} \\
\hline
\end{tabular}




$$
\text { media. }
$$

Asymmetric chemical Synthesis

Neoliths

Hyperthermophile

Hypolith

Metallophiles

Oligotroph

Piezophile
Organism that grows Upper subsurface to deep and lives inside rocks subterranean, Mediterranean and Japan Seas

Organism that grows at Submarine Hydrothermal temperature optimum Vents, East Pacific, as Porto of $80^{\circ} \mathrm{C}$ or higher

di Levante, Vulcano, Italy

Organism that grows Desert, Rock, Cornwallis and lives inside rocks Island and Devon Island in in cold deserts the Canadian high Arctic

$$
\begin{aligned}
& \begin{array}{l}
\text { Organisms } \\
\text { characteristics }
\end{array} \text { with } \begin{array}{l}
\text { Heavy metals, Latin America, } \\
\text { and Europe }
\end{array}
\end{aligned}
$$

specially, is capable to

tolerate high levels of

heavy metals, such as

copper, cadmium,

arsenic, and zinc

Organism capable to Carbon source, or carbon grow in nutritionally concentration, Antarctic deplete habitats

Organism that grows Deep Ocean eg. Mariana
and lives with Trench, Antarctic ice
optimum at hydrostatic
pressures of $40 \mathrm{MPa}$ or
higher

Shewanella,

$$
\text { Colwellia }
$$

hadaliensis

Moritella, and

Psychromonas 
Psychrophile

Organism that grows at Ice, Snow, Antarctic ice and temperature between Arctic Ocean $10-20^{\circ} \mathrm{C}$

Bacillus,
Clostridium,
Actinomycetes,
Pseudoalteromonas
Betaproteobacteria

Dehydrogenases

resistant to high levels radiation, Brazil

of ionizing radiation

Organism that can Hot Spring, Grand Prismatic prosper at temperatures Spring, Yellowstone National between $60^{\circ} \mathrm{C}$ and Park, USA

$85^{\circ} \mathrm{C}$ humidity
Proteases

Amylase

Cellulases

$* \mathrm{NI}$

\section{Detergents, food applications.}

Detergents and bakery.

Detergents feed and textiles.

Biosensors

$* \mathrm{NI}$

Lipase

$$
\begin{gathered}
\text { Additive to detergents for } \\
\text { washing at room }
\end{gathered}
$$
temperature.

Protease

\section{Breaking down of lipid} stains.

Breaking down of protein

$$
\text { stains. }
$$

Detergents in food and feed,

brewing, baking.

Biodiesel production by

transesterification of oils and

$$
\text { alcohols. }
$$

Flavor modification,

optically active

$$
\text { esters. }
$$

Amylases

Pullulanase

Starch, cellulose, chitin, and pectin processing, textiles.

$[85,86]$
Breakdown starch-based stains.

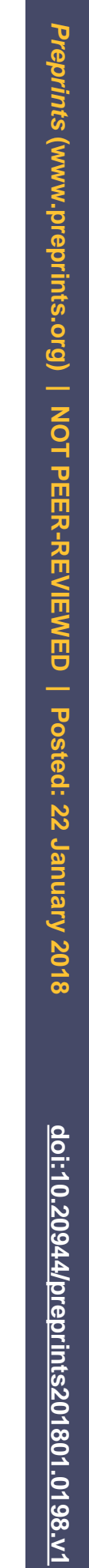


Starch hydrolysis.
Clarification of fruit,

egetable juices, and wine.

Cheese ripening.

Dough fermentation, bakery products.

Chitin modifications for food and health products.

Chitanases

Esterases

Polymerases

Dehydrogenases

Mannanase

Organisms capable to Water saturated with benzene resist at high levels of or

damaging agents, such Water-core of a nuclear

as organic solvents

reactor

National Park, USA
Conversion of cellulose to

$$
\text { ethanol. }
$$

Paper bleaching.

Bioremediation, degradation and removal of xenobiotics

and toxic

Detergents, stereospecific reactions

Molecular biology.

Oxydation reaction.

Degradation of mannan or gum

$* \mathrm{~N}$ 
grow at low water Atacama Desert in Chile

activity and resistant to

high desiccation

*NI: No Information 